\title{
GENERALIZED STATUS EPILEPTICUS ASSOCIATED WITH MASSIVE PULMONARY ASPIRATION AND TRANSIENT CENTRAL DIABETES INSIPIDUS
}

\author{
CASE REPORT
}

\author{
MAURICIO CARVALHO*, JOSÉ RONALDO MAYER JUNIOR**, \\ MONNICA ROSAS ROCHA*, RODRIGO KRUGER** JOÃO ALCEU TITTON***
}

\begin{abstract}
Status epilepticus causes significant morbidity and mortality. A case of generalized status epilepticus followed by massive pulmonary aspiration, acute respiratory failure and transient central diabetes insipidus is presented. Seizures were promptly controlled, but the patient required mechanical ventilation and correction of polyuria with desmopressin acetate. During hospitalization mental status improved, diabetes insipidus spontaneously remitted and he was discharged without neurologic sequelae. The clinical and pathophysiological features of this case are discussed.
\end{abstract}

KEY WORDS: status epilepticus, central diabetes insipidus, neurohypophysis.

Estado de mal epiléptico associado a aspiração pulmonar maciça e diabetes insípido central transitório: relato de caso

RESUMO - O estado de mal epiléptico causa morbidade e mortalidade significativas. Relatamos um caso de mal convulsivo generalizado, associado à aspiração pulmonar maciça, insuficiência respiratória aguda e diabetes insípido central transitório. As convulsões foram rapidamente controladas, porém o paciente necessitou de ventilação mecânica e correção da poliúria com acetato de desmopressina. Durante a hospitalização o nível de consciência normalizou-se, houve remissão espontânea do diabetes insípido e o paciente recebeu alta sem seqüelas neurológicas. São discutidos aspectos clínicos e patogênicos desta condição clínica.

PALAVRAS-CHAVE: estado de mal epiléptico, diabetes insípido central, neuro-hipófise.

The term status epilepticus (SE) refers to the occurrence of a single unremitting seizure or frequent clinical seizures without an interictal return to normal consciousness ${ }^{1,2}$. A range of mortality rates between one and fifty percent has been reported in different study groups ${ }^{3}$. Acute process that cause SE include metabolic disturbances, central nervous system infection, stroke, head trauma, drug toxicity, and hypoxia ${ }^{4}$. Seizures in this last category are associated with a higher mortality, especially in older patients 5 .

Central diabetes insipidus is caused by failure to normally synthesize or secrete vasopressin. It is a polyuric disorder characterized by high rates of electrolyte-free water excretion. Lack of

Serviço de Emergência Central, Departamento de Clínica Médica, Hospital de Clínicas (HC) da Universidade Federal do Paraná (UFPR). *Médico, Serviço de Emergência Central, HC-UFPR; **Médico Residente do Departamento de Clínica Médica do HC-UFPR; ***Professor Adjunto do Departamento de Clínica Médica e Chefe do Serviço de Emergência Central do HC-UFPR. Aceite: 4-julho-2000.

Dr. Mauricio Carvalho - Rua Chichorro Jr 144/142 - 80035-040 Curitiba PR - Brasil. Fax (41)262 7658. E-mail: carvalho@mais.sul.com.br 
vasopressin can be caused by disorders that act at one or more of the sites involved in vasopressin secretion: the hypothalamic osmoreceptors; the supraoptic or paraventricular nuclei; or the superior portion of the supraopticohypophyseal tract $^{6}$.

This paper describes a case of status epilepticus complicated by massive pulmonary aspiration, acute respiratory failure and transient central diabetes insipidus.

\section{CASE REPORT}

A 37-year-old man with a previously well-controlled seizure disorder was brought to the emergency room of the Hospital de Clínicas da Universidade Federal do Paraná with recurrent, generalized tonic-clonic seizures that persisted for 2 hours. He had a history of chronic alcohol abuse and was taking no medications. At admission, the patient was unresponsive with frequent generalized tonic-clonic seizures. The pupils, fundus, and extraocular movements were normal. Cranial-nerve functions were intact. There were no focal motor findings. The patient was intubated and mechanically ventilated. During the procedure he vomited and aspirated a large amount of gastric content. He was treated with IV diazepam $10 \mathrm{mg}$, glucose, thiamine and IV phenytoin $1200 \mathrm{mg}$ at $50 \mathrm{mg} / \mathrm{min}$, with resolution of seizure activity. Initial laboratory data revealed a hemoglobin concentration of $12 \mathrm{~g} / \mathrm{dL}$ and a whitecell count of 8,300 per $\mathrm{mm}^{3}$, with a mild leftward shift. Serum sodium was $130 \mathrm{mEq} / \mathrm{L}$, potassium was $4 \mathrm{mEq} / \mathrm{L}$, and BUN, creatinine and glucose were normal. An arterial blood gas analysis revealed a pH of 7.3, a pCO2 of 35.4 $\mathrm{mmHg}$ and a pO2 of $53 \mathrm{mmHg}$ on $100 \%$ oxygen. Chest X-ray studies displayed bilateral patchy alveolar infiltrates greatest at the right apex. A head CT scan was normal, and an EEG showed a diffuse slowing pattern and no seizure activity. In the first six hours of hospitalization the patient developed a urine output of $400 \mathrm{~mL} / \mathrm{hour}$ that increased rapidly to $600 \mathrm{~mL} /$ hour over the next four hours. The serum sodium increased to $142 \mathrm{mEq} / \mathrm{L}$ and urine sodium concentration was $70 \mathrm{mEq} / \mathrm{L}$. Persistent hyposthenuria developed, with a urine specific gravity of 1.005 , a plasma osmolarity of $290 \mathrm{mOsm} / \mathrm{L}$ and a urine osmolarity of $200 \mathrm{mOsm} / \mathrm{L}$. Diabetes insipidus was diagnosed and the IV infusion rate was increased to maintain an equal fluid balance. Desmopressin acetate (DDAVP) administered intranasally caused a reduction in urinary output to less than $50 \mathrm{~mL} /$ hour with a significant rise in urine osmolarity. During the next 48 hours the patient had severe polyuria (14 and 10 liters in the second and third day of hospitalization, respectively, despite high doses of DDAVP), and continued to require mechanical ventilatory support. In the fourth day repeated arterial blood gas analysis markedly improved and the urinary output was less than 2 liters. Mental status normalized and DDAVP was discontinued. The patient was removed from the ventilator and extubated in the sixth day. He was discharged 10 days after the admission without neurologic sequelae.

\section{DISCUSSION}

Acute and chronic processes can trigger SE. Discontinuation or use of low doses of antiepileptic drugs are prominent causes of $\mathrm{SE}^{4}$. When it occurs, the treatment should proceed on four fronts: termination of SE, prevention of recurrence, control of precipitating causes, and management of complications ${ }^{7}$. The major complications of generalized convulsive SE are rhabdomyolysis, hyperthermia, cardiac arrhythmias and aspiration pneumonia ${ }^{8}$.

The syndrome of aspiration pneumonia is due to the parenchymal inflammatory reaction caused by a large volume of aspirated liquid gastric contents. After aspiration, patients develop tachypnea, fever, crackles, severe hypoxemia, and localized or diffuse chest X-ray abnormalities that progress within 24 to 36 hours ${ }^{9,10}$.

In the case reported herein, the sum of SE and massive pulmonary aspiration caused acute respiratory failure coincidental with a polyuric pattern characterized as central diabetes insipidus (CDI). The low sodium and urinary osmolarity excluded cerebral salt wasting, a relatively common clinical situation caused by secretion of brain natriuretic peptide ${ }^{11}$.

Hypoxic/ischemic encephalopathy is very rarely associated with central diabetes insipidus ${ }^{12-14}$. Generally is an ominous sign of severe brain damage. In a recent report, Arisaka et al. ${ }^{15}$ describe two children who after cardiopulmonary arrest developed hypernatremia at the terminal stage. Urinary antidiuretic hormone concentration was very low, indicating CDI.

The mechanism by which SE is linked to CDI is obscure. SE has the potential to cause injury due to the metabolic stress of repeated muscular convulsions and intense neuronal activity within 
the central nervous system ${ }^{16}$. The superimposition of systemic stresses such hyperthermia or hypoxia can exacerbate the degree of neuronal injury ${ }^{4}$.

There are reports of significant reductions in neuronal densities in human $\mathrm{SE}^{17}$. Also, there are occasional pathologic findings of scarring and atrophy in the supraoptic nuclei and posterior pituitary gland in $\mathrm{CDI}^{18}$. We postulate that in this case neuronal damage to the tract below the median eminence or to the posterior pituitary caused transient CDI. In this situation, vasopressin produced in the hypothalamus can still be secreted into the systemic circulation via the portal capillaries in the median eminence ${ }^{6}$.

\section{REFERENCES}

1. Aminoff MJ, Simon RP. Status epilepticus: causes, clinical features and consequences in 98 patients. Am J Med 1980;69:657-666.

2. Epilepsy Foundation of America's Working Group on Status Epilepticus. Treatment of convulsive status epilepticus: recommendations. JAMA 1993;270:854-859.

3. Hauser WA. Status epilepticus: epidemiologic considerations. Neurology 1990;40(Suppl 2):9-13.

4. Lowenstein DH, Alldredge BK. Status epilepticus. N Engl J Med 1998;338:970-976.

5. Towne AR, Pellock JM, Ko D, DeLorenzo RJ. Determinants of mortality in status epilepticus. Epilepsia 1994;35:27-34.

6. Rose BD. Clinical Physiology of acid-base and electrolyte disorders, 4Ed, New York: McGraw-Hill, 1994:699-702.

7. Bleck TP. Management approaches to prolonged seizures and status epilepticus. Epilepsia 1999; 40(Suppl 1):S59-S63.

8. Wasterlain CG, Fujikawa DG, Penix L, Sankar R. Pathophysiological mechanisms of brain damage from status epilepticus. Epilepsia 1993;34(Suppl 1):S37-S53.

9. Awe WL, Fletcher WS, Jacob SW. The pathophysiology of aspiration pneumonitis. Surgery 1966;60:232-239.

10. Little JW. Pulmonary aspiration. West J Med 1979;131:122-129.

11. Berendes E, Walter M, Cullen P, et al. Secretion of brain natriuretic peptide in patients with aneurysmal subarachnoid haemorrhage. Lancet 1997;349:245-249

12. Rothschild M, Shenkman L. Diabetes insipidus following cardiorespiratory arrest. JAMA 1977;238:620-621.

13. Glauser FL. Diabetes insipidus in hypoxemic encephalopathy. JAMA 1976;235:932-933.

14. Lee YJ, Huang FY, Shen EY, et al. Neurogenic diabetes insipidus in children with hypoxic encephalopathy: six new cases and a review of the literature. Eur J Pediatr 1996;155:245-248.

15. Arisaka O, Arisaka M, Ikebe A, et al. Central diabetes insipidus in hypoxic brain damage. Childs Nerv Syst 1992;8:81-82.

16. Payne TA, Bleck TP. Status epilepticus. Crit Care Clin 1997;13:17-38.

17. DeGiorgio CM, Tomiyasu U, Gott PS, Treiman DM. Hippocampal pyramidal cell loss in human status epilepticus. Epilepsia 1992;33:23-27.

18. Jialal I, Desai RK, Rajput MC. An assessment of posterior pituitary function in patients with Sheehan's syndrome. Clin Endocrinol 1987;27:91-95. 